\title{
Pembelajaran Menulis Teks Deskripsi Menggunakan Media Sosial Instagram
}

\author{
Indah Fauziah* \\ E-mail: indah.fauziah0587@ student.unri.ac.id \\ *Program Studi Pendidikan Bahasa dan Sastra Indonesia, Universitas Riau
}

\section{Pengantar}

Di zaman saat ini tidak dapat dipungkiri bahwa perkembangan serta kemajuan teknologi sangatlah pesat. Begitu juga dengan penggunaan media sosial yang tidak terbatas pada komunitas kalangan. Melainkan, sudah tersebar di seluruh lapisan kalangan terkhusus kalangan remaja. Media sosial yang dimaksud salah satunya adalah instagram. Instagram adalah sebuah media komunikasi yang relatif baru di mana pengguna dapat membagikan pembaruan mereka serta mengirimkan foto atau video (Hu et al., 2014). Hal menarik dari instagram adalah sebuah fitur yang dapat menambahkan sebuah teks yang biasa disebut caption untuk memberi penjelasan terhadap gambar atau video yang diunggah.

Dalam ketenaran sebuah media sosial tersebut ada sisi yang sangat disayangkan, karena dinilai lebih banyak dampak negatif yang ditimbulkan dari penggunaan media sosial instagram seperti penyebaran konten SARA, hoaks, dan lain-lain terutama di kalangan pelajar (Afrizal, 2020). Oleh karena itu, dibutuhkan sebuah inovasi agar media sosial khususnya instagram dapat dimanfaatkan sebaik mungkin dalam suasana belajar. Seperti halnya sebagai media pembelajaran menulis teks deskripsi dan tentunya para peserta didik dapat mempraktikkan secara langsung menulis teks deskripsi tentang gambar yang dilihat dan juga diamati. Dengan ini sebuah media dapat mendukung dan memberikan manfaat dalam menciptakan pembelajaran yang menarik dan menyenangkan, salah satunya adalah penggunaan media sosial instagram dalam pembelajaran menulis teks deskripsi. Sehingga, media sosial menjadi sesuatu yang bermanfaat bagi pelajar. 


\section{Tindakan yang Dilakukan}

\section{a. Pendidik}

Pendidik dalam ranah ini kita kenal dengan sebutan guru. Guru adalah sosok yang begitu dihormati karena memiliki tugas yang cukup besar terhadap keberhasilan kegiatan pembelajaran di sekolah. Guru sangat berperan dalam membantu tercapainya suatu pembelajaran yang unik dan menyenangkan, mampu membuat inovasi baru dalam sebuah pembelajaran dengan tujuan mencapai serta meningkatkan kemampuan dan karakter yang optimal, serta guru memiliki tanggung jawab dalam membimbing dan membina peserta didik untuk selalu berkreasi dalam proses belajar mengajar (Hamid, 2017).

Dalam sebuah pembelajaran guru dituntut untuk memberikan sebuah pemahaman atau pencerahan terhadap inovasi atau sesuatu hal yang akan ia lakukan. Guru ialah insan yang mempunyai keahlian dalam mencurahkan suatu uraian dan pencerahan baik etika maupun aspek kerohanian kepada setiap orang (Zulhafizh, 2013). Dengan ini guru dapat memberikan pemahaman serta pencerahan terlebih dahulu terkait sebuah inovasi pembelajaran yang akan dijalankan agar hasil yang didapatkan nantinya baik dan tentunya tidak melanggar etika dan spiritual seorang peserta didik.

Dalam proses pembelajaran guru juga dapat mengolaborasikan antara ide atau inovasinya, namun hal itu harus seimbang dengan sikap kepribadian dan sikap profesional. Di mana diungkapkan oleh Mulyasa (2005) bahwa guru yang profesional ialah guru yang memiliki: (1) Kompetensi pedagogik, yaitu kemampuan yang berkenaan dengan sebuah pemahaman peserta didik dan pengelola pembelajaran yang mendidik, yang mencakup kemampuan perancangan dan pelaksanaan pembelajaran, evaluasi terhadap hasil belajar, dan pengembangan siswa untuk mengaktualisasikan berbagai potensi yang berawal dari inovasi yang dimilikinya. (2) Kompetensi kepribadian, yaitu kemampuan secara individu yang mencerminkan kepribadian yang dewasa, mantap, arif, stabil, dan juga berwibawa dalam segala hal. (3) Kompetensi sosial, yakni berkenaan dengan kemampuan 
guru sebagai bagian dari masyarakat untuk berkomunikasi secara efektif dengan siswa, warga sekolah dan juga masyarakat, baik dalam media secara langsung ataupun dalam media sosial.

Perihal di atas pula tidak dapat terlepas begitu saja dari seluruh kompetensi yang dipunya yakni suatu motivasi yang diberikan oleh guru dalam melakukan aktivitas pendidikan. Sehingga guru dalam menjalankan pembelajaran yang bernuansa berbeda, siswa akan terus termotivasi dengan segala keadaan, sebab motivasi dapat mendorong siswa untuk menerapkan pembelajaran guna mendapatkan hasil dari proses belajarnya itu dan tentunya siswa akan berusaha mencari cara untuk menerapkan pembelajaran, baik itu menulis ataupun yang sedang dipelajarinya. Motivasi belajar sangat diperlukan dalam belajar, motivasi ini adalah penggerak bagi siswa dalam belajar guna memperoleh hasil yang maksimal (Zulhafizh, Atmazaki, \& Syahrul, 2013). Seperti halnya dalam memotivasi serta memberikan inovasi terhadap siswa mengenai pembelajaran yang memanfaatkan media sosial, seperti media sosial instagram.

Sedangkan menurut Wardana (2013) guru atau pendidik adalah komponen yang paling menentukan dalam sistem pembelajaran secara keseluruhan, yang harus mendapat perhatian sentral, pertama, dan utama, serta sebagai sumber daya manusia yang menjadi perencanaan, pelaku dan penentu tercapainya tujuan sebuah pendidikan.

\section{b. Peserta Didik}

Peserta didik adalah manusia seutuhnya yang berupaya mengasah kemampuan agar lebih potensial dengan bantuan atau dorongan pendidik atau orang dewasa. Secara terminologi, peserta didik berarti anak didik atau individu yang mengalami perubahan dan perkembangan yang mengalami proses pembelajaran yang pada umumnya memiliki kebutuhan-kebutuhan wajib dan mendasar yang harus dipenuhi dan tidak bisa dihindarkan dalam artian diberi didikan atau bimbingan oleh seseorang yang lebih dewasa darinya seperti guru ataupun sosok yang lainnya (Devianti \& Sari, 2020; Harahap, 2016). Menurut 
Danim dalam Agustina (2018) peserta didik adalah bentuk nama secara sah yang sudah dilegalkan oleh badan hukum terutama badan hukum kependidikan yang mengubah atau menggantikan sebutan murid, siswa atau pelajar. Namun, sebutan tersebut tidak menjadi hal yang sama persis terjadi di dalam dunia pendidikan. Karena, secara konvensional sebutan yang lainnya akan terucap atau tersampaikan dalam proses pendidikan itu sendiri. Di dalam UU No. 20 Tahun 2003 Tentang Sistem Nasional Pendidikan, peserta didik dapat diartikan seseorang yang selalu mengembangkan kemampuan dirinya baik dalam proses pembelajaran formal di sekolah ataupun nonformal, dan pada jenjang ataupun jenis pendidikan tertentu. Hal ini peserta didik diberi kebebasan oleh pendidik dalam mengeksplorasikan sebuah pembelajaran yang tentunya memanfaatkan kecanggihan sebuah teknologi seperti berbagai aplikasi media sosial untuk melatih tingkat pembelajaran, motivasi, serta daya kreativitas.

\section{c. Diklat Pembelajaran Menulis Teks Deskripsi Menggunakan Media Sosial Instagram}

Pembelajaran pada hakikatnya ialah kemampuan guru dan peserta didik dalam berkomunikasi yang dalam penyampaian komunikasi tersebut diperlukan sebuah sarana, sarana yang dimaksud adalah media (Afrizal, 2020). Santoso dalam Subana (2009: 287) mengemukakan bahwa media adalah keseluruhan bentuk perantara yang digunakan oleh seseorang dalam menyebarkan ide atau gagasan sehingga gagasan ataupun ide tersebut tersampaikan kepada si penerima. Dalam aktivitas pembelajaran media itu sendiri digunakan untuk belajar mengajar dari seorang pendidik ke peserta didik agar materi yang disampaikan dapat tersalurkan dengan baik. Media yang digunakan ini tentunya memanfaatkan teknologi dalam hal ini adalah sebuah aplikasi media sosial berupa media sosial instagram.

Aktivitas pembelajaran yang dilakukan dengan menggunakan media sosial instagram ini tentunya ada sisi keuntungan yang dapat diambil. Salah satunya adalah untuk kegiatan belajar menjadi menarik, menginovasi, memotivasi, 
menyenangkan, dan membuat peserta didik belajar lebih baik. Karena peserta didik inilah yang menjadi pelaku utama dalam melakukan kegiatan pembelajaran menulis teks deskripsi.

Teks deskripsi merupakan sebuah teks berupa rangkaian kalimat yang menjelaskan atau menggambarkan sesuatu, baik itu berdasarkan pengetahuan maupun pengalaman oleh penuturnya (Sumarlam, 2003). Pendapat lain menjelaskan bahwa deskripsi adalah sebuah bentuk tulisan yang mampu memberikan sebuah rincian-rincian atas sebuah objek (Keraf, 1981: 93). Terkait pengertian dari teks deskripsi tersebut, tentunya teks deskripsi mempunyai sebuah fungsi agar setiap pembaca dapat memahami dan mengetahui maksud dari objek yang sedang dibicarakan atau dibahas.

Instagram mempunyai beberapa fitur atau fungsi yang sangat sesuai dengan pembelajaran menulis teks deskripsi. Fitur tersebut antara lain fitur pemberian caption atau tulisan yang dapat ditambahkan di bawah gambar yang berfungsi sebagai penjelasan isi gambar. Fitur ini cocok digunakan oleh guru dan juga siswa, bagi guru dapat memberikan sebuah contoh penulisan teks teks deskripsi yang sesuai. Adapun bagi siswa fitur tersebut dapat digunakan oleh siswa dalam mempraktikan secara langsung menulis teks deskripsi mengenai gambar yang diunggahnya sendiri di akun miliknya. Fitur selanjutnya adalah kolom komentar. Kolom komentar ini dapat digunakan oleh guru dalam mengoreksi hasil teks deskripsi yang telah dibuat. Hal ini tidak menutup kemungkinan bagi siswa lain untuk memberikan sebuah deskripsi terhadap gambar yang diunggah temannya itu. Lalu ada fitur tandai (tag) dan fitur sebut (mention). Fitur tersebut bisa dimanfaatkan guru dalam melacak tulisan siswa, yakni dengan cara siswa menandai akun instagram guru dalam gambar yang telah diunggah lalu siswa menyebut nama akun instagram guru pada teks deskripsinya. Diklat pembelajaran menulis teks deskripsi menggunakan media sosial instagram dapat dilakukan sebagai berikut: 
Pertama, guru memberikan contoh berupa penyusunan atau penulisan teks deskripsi yang baik pada sebuah gambar atau foto, kemudian mengunggah gambar beserta deskripsi tersebut pada akun instagramnya. Lalu guru mengarahkan kepada siswanya untuk melihat unggahan tersebut. Tentunya pada tahap ini guru memaparkan proses atau langkah membuat teks deskripsi, yaitu dengan memberi penjelasan tentang struktur dan juga jenis-jenis deskripsi. Struktur teks deskripsi itu sendiri terdiri dari identifikasi, deskripsi bagian, dan penutup (Harsiati et al., 2017: 18-19). Adapun jenis-jenis deskripsi menurut Indiyastini (2009) diantaranya (1) deskripsi tentang benda; (2) deskripsi tentang binatang; (3) deskripsi tentang orang; (4) deskripsi tentang suasana; dan (5) deskripsi tentang tempat. Menurut Imawati (2017) jenis deskripsi atau sumber pendeskripsiannya dalam teks deskripsi dapat dibedakan menjadi (a) deskripsi keadaan fisik; (b) deskripsi keadaan sekitar; (c) deskripsi orang; (d) deskripsi watak atau tingkah laku; dan (e) deskripsi tempat.

Selesai siswa mengamati teks deskripsi yang telah dicontohkan sebelumnya, kemudian siswa mencoba mempraktikan menulis deskripsi dari suatu gambar. Tahap ini tentunya memunculkan dua cara yang dapat dilakukan yaitu:

Pertama, siswa dapat mendeskripsikan gambar dengan individu atau sendiri. Hal ini siswa tersebut harus mengunggah sebuah gambar lalu menuliskan perihal deskripsi yang ia buat dalam gambar yang telah diunggah sebelumya. Deskripsi yang dibuat tentunya harus sesuai dengan teks deskripsi yang telah dijelaskan oleh guru. Dalam artian deskripsi yang dibuat harus sesuai aturan dan tidak singkat atau hanya berupa judul.

Cara yang kedua adalah dengan mendeskripsikan gambar yang sudah diunggah oleh teman sebaya. Bukan memberikan sebuah komentar, namun siswa yang lain dapat mendeskripsikan gambar temannya. Sehingga guru dapat mengetahui serta membandingkan tingkat pemahaman antar siswa.

Langkah terakhir yang dapat dilakukan dalam diklat pembelajaran menulis teks deskripsi menggunakan media sosial instagram adalah guru memberikan 
penilaian serta nasihat atau saran terhadap teks deskripsi yang telah dibuat oleh masing-masing siswa dengan memfungsikan kolom komentar. Dengan hal itu para siswa dapat melihat dan membaca perihal evaluasi atau koreksi yang diberikan oleh guru kepada masing-masing siswa. Sehingga para siswa akan terus berlatih dan belajar bagaimana menulis teks deskripsi yang benar dan juga apik.

\section{Sarana Pendukung}

Sarana adalah segala sesuatu yang bisa digunakan sebagai alat dalam mencapai tujuan atau maksud (Pusat Bahasa Kemdikbud, 2016). Sarana ini sama halnya dengan wadah yang merupakan arti dari sebuah media (Hamzah, 2015). Pendukung erat kaitannya dengan segala sesuatu yang harus ada dalam sebuah proses atau kegiatan. Sehingga sarana pendukung ini adalah segala sesuatu yang menjadi alat dalam menjalankan sebuah media untuk mencapai maksud atau tujuan tertentu. Dalam hal itu pembelajaran menulis teks deskripsi menggunakan media sosial instagram tentunya harus memiliki sarana pendukung agar kegiatan menulis tersebut dapat terlaksana dengan baik. Adapun sarana pendukung dalam pembelajaran menulis teks deskripsi menggunakan media sosial instagram adalah:

\section{a. Handphone}

Handphone adalah sebuah peralatan atau alat teknologi yang sangat praktis untuk digunakan berkomunikasi di manapun berada, mudah dibawa kemanamana, mudah digunakan dan penggunaannya tanpa dibatasi oleh ruang dan rentang panjang kabel (Farida et al., 2021; Mulyata, 2005). Sarana pendukung yang pertama dalam pembelajaran menulis teks deskripsi menggunakan media sosial instagram tentunya adalah handphone karena menjadi alat atau piranti yang utama dalam proses praktik yang akan dilakukan oleh siswa.

\section{b. Jaringan Internet}

Internet adalah salah satu sarana yang sangat dibutuhkan dalam kehidupan sehari-hari. Bagaimana tidak? Internet menjadi wadah dalam mencari sebuah informasi atau menemukan berbagai hal yang ada di dalam perangkat lunak yang 
tersambung dengan koneksi internet. Khozaimi (2017) internet adalah sebuah sarana yang menjadi salah satu kebutuhan oleh para peserta didik saat ini, internet dapat membantu memperoleh informasi serta berbagai referensi. Jaringan internet menjadi pelengkap dalam berbagai sektor dan tidak terlepas dari berbagai aktivitas, terlebih pada saat ini yang dapat dijumpai hampir semua aplikasi, baik itu desktop, website, mobile, yang difungsikan dalam lapisan bidang, baik bidang pendidikan, bank, logistik, transportasi dan lain-lain (Rahman et al., 2020). Dalam (Pusat Bahasa Kemdikbud, 2016) internet adalah jaringan komunikasi elektronik yang mampu menghubungkan dan memberi fasilitas terhadap komputer agar terorganisasi melalui satelit atau telepon di seluruh dunia.

Dari beberapa pengertian di atas, maka sarana ini menjadi hal yang sangat mendukung adanya pembelajaran menulis teks deskripsi menggunakan media sosial instagram. Dengan ini sebuah aplikasi akan berjalan apabila memiliki koneksi atau jaringan yang cepat dan stabil. Sehingga, aktivitas pembelajaran itu dapat tercapai dengan baik.

\section{c. Paket Data (Internet)}

Paket data internet atau sering disebut dengan kuota internet menjadi sarana yang sangat mendukung demi tercapainya pembelajaran ini. Sebab, jika tidak ada kuota internet maka aktivitas pembelajaran menulis teks deskripsi tidak dapat berjalan, sebagian besar siswa tentunya menggunakan kuota internet demi menjalankan aplikasi yang ada di dalam handphone-nya tidak terkecuali media sosial instagram. Dengan adanya kuota internet ini guru dan para siswa dapat melaksanakan kegiatan pembelajaran tersebut tentu sebelumnya masing-masing siswa memiliki gawai dan berada dalam kondisi jaringan internet yang stabil.

\section{d. Aplikasi Instagram}

Instagram adalah sebuah media komunikasi yang relatif baru di mana pengguna dapat membagikan pembaruan mereka serta mengirimkan foto atau video (Hu et al., 2014). Media sosial instagram ini menjadi sarana pendukung dalam mempraktikan pembelajaran menulis teks deskripsi. Instagram ini menjadi 
media atau sarana yang menjadi wujud, bentuk, serta sarana hasil dari kegiatan pembelajaran tersebut. Aplikasi instagram ini dapat dijalankan tentu dengan adanya handphone, kuota internet, dan jaringan internet.

\section{Tindakan Solutif}

Seorang pendidik atau guru dalam sebuah pembelajaran harus mampu dalam mengelola sebuah inovasi dan mampu dalam menciptakan sebuah solusi apabila inovasi yang dijalankan tidak berada pada tempatnya. Mustafa, Hermandra, \& Zulhafizh, (2019) seorang guru harus mampu menjadi pembuat solusi sekaligus pemecah masalah bagi dirinya dan juga peserta didiknya. Ketika suatu kendala atau halangan muncul saat proses belajar mengajar atau aktivitas yang sedang dilakukan, maka guru harus mampu bertindak dalam upaya mengatasi agar kegiatan menulis teks deskripsi menggunakan media sosial instagram tetap berjalan dengan baik. Perihal ini tidak dapat terlepas dari sebuah tindakan atau aksi solutif yang dapat dicoba oleh seorang guru ataupun siswa. Tindakan solutif tersebut antara lain:

a. Jika ada beberapa siswa yang tidak atau belum memiliki alat piranti digital seperti handphone maka setiap siswa dapat meminjam atau membeli perangkat tersebut. Jika masih tidak memungkinkan, siswa dapat menggunakan handphone orang tua masing-masing atau bisa juga berkunjung ke rumah teman sejawat untuk belajar bersama serta meminta tolong (meminjam akun instagram) agar dapat menulis teks deskripsi yang nantinya diunggah ke media sosial instagram, namun tetap mencantumkan nama pemilik atau pembuat teks deskripsi, hal ini tentunya sudah diketahui oleh guru. Solusi yang dapat dilakukan oleh guru salah satunya adalah dengan membagi siswa dalam beberapa kelompok (Khasanah, 2018). Dengan hal ini dapat meminimalisir bagi siswa yang belum atau tidak memiliki handphone.

b. Jika ada sebagian siswa yang memiliki kendala dalam hal jaringan, sehingga tidak dapat memposting gambar serta caption teks deskripsi ke media sosial instagram. Maka tindakan solutif yang dapat dilakukan adalah siswa dapat 
mencari atau mengusahakan di mana sumber atau tempat adanya jaringan yang stabil.

c. Jika tidak adanya atau kurangnya kuota internet atau paket data maka siswa dapat membeli paket data internet atau meminta bantuan hostpot perangkat lain yang terhubung ke jaringan internet hal ini bisa teman, guru ataupun orang tua. Solusi lainnya adalah dengan mencari atau menggunakan Wi-Fi sekitar apabila jaringan tersebut terkoneksi dengan baik.

d. Jika aplikasi belum atau tidak terinstal/terunduh serta terkendala dalam mengoperasikannya maka solusinya guru memberikan arahan atau bimbingan untuk menginstal aplikasi tersebut di App Market atau Play Store di handphone masing-masing sesuai dengan keperluan dan dapat mempelajari cara menggunakannya atau mengoperasikannya dari berbagai macam sumber. Misalnya mencari di google, tutorial YouTube, melalui guru, orang tua, atau teman sejawat yang sudah mahir menggunakan dan atau mengoperasikan media sosial instagram tersebut.

e. Tindakan solutif yang lainnya adalah jika para siswa merasa sulit dalam mencurahkan ide yang akan dideskripsikan maka guru dapat memberikan sebuah media berupa gambar karena dalam media gambar ini siswa akan terbantu dan lebih mudah dalam mendeskripsikannya (Fajriyati, 2020).

\section{Simpulan}

Era digital yang terjadi saat ini harus ada usaha dari segenap lapisan masyarakat terutama bagi seorang guru dalam menyeimbangkan sebuah teknologi dan tentunya dapat menekan dampak negatif dan memperluas manfaat yang diberikan oleh kemajuan teknologi ini. Guru menjadi agen penggerak dalam memberikan dampak positif dari media sosial. Salah satunya adalah dengan memanfaatkan media sosial sebagai sarana pembelajaran. Sehingga dapat mengarahkan dan memberikan kesan belajar yang menarik kepada siswa. Salah satu upaya memanfaatkan media sosial adalah pembelajaran menulis teks deskripsi menggunakan instagram. Hal ini akan menjadi sesuatu yang bermanfaat yakni menjalankan sebuah roda pembelajaran dengan kemajuan teknologi digital. 


\section{Referensi}

Afrizal, D. Y. (2020). Media Sosial Instagram Sebagai Sarana Pembelajaran Menulis Teks Deskripsi. Prosiding Samata: Seminar Nasional Bahasa Dan Sastra Indonesia, 62-66.

Agustina, N. (2018). Perkembangan Peserta Didik. Yogyakarta: Deepublish.

Devianti, R., \& Sari, S. L. (2020). Urgensi Analisis Kebutuhan Peserta Didik Terhadap Proses Pembelajaran. Jurnal Al-Aulia, 06(01), 21-36. https://ejournal.stai-tbh.ac.id/index.php/al-aulia/article/view/189

Fajriyati, N. (2020). Pemanfaatan Media Sosial Instagram untuk Meningkatkan Keterampilan Menulis Deskripsi Mapel BI Bagi Siswa Kelas VII SMP Muhammadiyah Pangkalan Bun. 1-22. https://core.ac.uk/download/pdf/345242250.pdf.

Farida, A., Salsabila, U. H., Hayati, L. L. N., Ramadhani, J., \& Saputri, Y. (2021). Optimasi Gadget dan Implikasinya Terhadap Pola Asuh Anak. Jurnal Inovasi Penelitian, 1(8), 1701-1710.

Hamid, A. (2017). Guru Profesional. Al Falah, XVII(32), 274-285.

Hamzah, R. E. (2015). Penggunaan Media Sosial di Kampus dalam Mendukung Pembelajaran Pendidikan. Wacana, XIV(1), 45-70.

Harahap, M. (2016). Esensi Peserta Didik dalam Perspektif Pendidikan Islam. Jurnal Al-Thariqah, 1(2), 140-155. https://doi.org/10.25299/althariqah.2016.vol1(2).625

Harsiati, T., Trianto, A., \& Kosasih, E. (2017). Bahasa Indonesia SMP/MTs Kelas VII. Jakarta: Kementerian Pendidikan dan Kebudayaan.

Hu, Y., Manikonda, L., \& Kambhampati, S. (2014). What We Instagram: A First Analysis of Instagram Photo Content and User Types. Proceedings of the Eighth International AAAI Conference on Weblogs and Social Media, 595-598.

Imawati, E. (2017). Pengaruh Pembelajaran Berbasis Teks Terhadap Kemampuan Menulis Teks Deskriptif. E-Jurnal LITERASI, 1(1), 53-63.

Indiyastini, T. (2009). Kohesi dan Koherensi Paragraf Deskriptif dalam Bahasa Jawa. Yogyakarta: Balai Bahasa Yogyakarta.

Keraf, G. (1981). Eksposisi dan Deskripsi. Ende: Nusa Indah.

Khasanah, M. (2018). Peningkatan Keterampilan Menulis Descriptive Text melalui Genre Based Approach Berbantuan Media Instagram. PAEDAGOGIE, 13(1), 9-19. 
Khozaimi, A. (2017). Implementasi Jaringan Point to Multipoint dengan Mikrotik RB 433 pada Jaringan Internet Asrama Mahasiswa Universitas Trunojoyo Madura. Jurnal Ilmiah NERO, 3(1), 53-60.

Mulyasa, E. (2005). Menjadi Guru Profesional. Bandung: PT Remaja Rosdakarya.

Mulyata, E. . S. (2005). Kupas Tuntas Telepon Seluler Anda. Yogyakarta: ANDI.

Mustafa, M. N., Hermandra, \& Zulhafizh. (2019). Teachers' Strategies to Design Media to Implement Communicative Leaning in Public Schools. Journal of Educational Sciences, 3(1), 13-24.

Pusat Bahasa Kemdikbud. (2016). Kamus Besar Bahasa Indonesia Edisi Kelima $(K B B I V)$. Badan Pengembangan Dan Pembinaan Bahasa, Kementerian Pendidikan Dan Kebudayaan Republik Indonesia.

Rahman, T., Sumarna, \& Nurdin, H. (2020). Analisis Performa RouterOS MikroTik pada Jaringan Internet. JURNAL INOVTEK POLBENG, 5(1), 178-192.

Subana, M. (2009). Strategi Belajar Mengajar Bahasa Indonesia. Bandung: Pustaka Setia.

Sumarlam. (2003). Teori dan Praktik Analisis Wacana. Surakarta: Pustaka Cakra.

UU No. 20 Tahun 2003 tentang Sistem Nasional Pendidikan.

Wardana, D. S. (2013). Motivasi Berprestasi dengan Kinerja Guru yang Sudah Disertifikasi. Jurnal Ilmiah Psikologi Terapan, 01(01), 98-109. http://ejournal.umm.ac.id/index.php/jipt/article/viewFile/1361/1456

Zulhafizh. (2013). Guru: Profesi yang Tak Lekang Oleh Waktu. Dialog Interaktif Profesi Kependidikan, 1-11. https://doi.org/doi: 10.31219/osf.io/39sk6

Zulhafizh, Atmazaki, \& Syahrul, R. (2013). Kontribusi Sikap dan Motivasi Belajar Siswa Terhadap Hasil Belajar Bahasa Inodonesia. Jurnal Bahasa, Sastra dan Pembelajaran, 1(2), 13-28. 


\section{*Data Penulis}

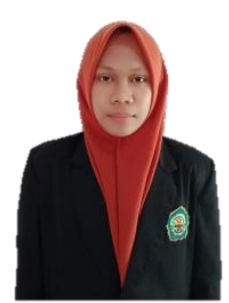

Indah Fauziah, lahir di Siak, 3 Desember 2001. Ia tamat dari MAS Al Muttaqien pada tahun 2020 dan Ia melanjutkan studi pada strata satu Jurusan Pendidikan Bahasa dan Seni di Program Studi Pendidikan Bahasa dan Sastra Indonesia FKIP Universitas Riau melalui jalur SNMPTN (Seleksi Nasional Masuk Perguruan Tinggi Negeri). Sekarang Ia sedang menempuh pendidikannya pada semester tiga di kampus tercinta.

Kontak:

Hp/WA : +6282269144648

Email : indah.fauziah0587@student.unri.ac.id 